\title{
Vecuronium is more potent in Montreal than in Paris
}

This study was undertaken to compare the potency of vecuronium in patients anaesthetized in Montreal or Paris. Anaesthesia was induced with thiopertone and maintained with $\mathrm{N}_{2} \mathrm{O}$, and intermittent boluses of thiopentone and fentanyl in 18 patients in Paris and 19 in Monireal. Neuromuscular blockade was measured using train-of-four stimulation of the ulnar nerve. The force of contraction of the adductor pollicis muscle was measured. Single doses of vecuronium, 20,30, or $40 \mu \mathrm{g} \cdot \mathrm{kg}^{-1}$ were given by random allocation. Dose response curves were constructed by obtaining the linear regression of the logit of the first response (TI) neuromuscular blockade versus log dose. The patients in Paris required $27 \%$ more vecuronium (95\% confidence limits 5-53\%; $P=0.011$ for the same intensity of blockade. In Montreal, the $E D_{50}$ and $E D_{90}( \pm S E E$ for the mean) values were $26.0 \pm 1.4$ and $44.2 \pm 2.5 \mu \mathrm{g} \cdot \mathrm{kg}^{-1}$ compared with $33.0 \pm 3.3$ and $71.9 \pm 7.2 \mu \mathrm{g} \cdot \mathrm{kg}^{-1}$ in Paris respectively. The patients were comparable with respect to age, sex, height and weight. These results confirm, for vecuronium, the transatlantic difference in potency of neuromuscular blocking drugs which was previously observed with $d$-tubocurarine berween London and New York.

Le but de cette étude était de comparer la puissance du vécuronium chez 19 sujets anesthésiés à Montréal et 18 sujets à Paris. Le thiopental a été utilisé pour induction de l'anesthésie, et l'entretien s'est effectué à l'aide de $\mathrm{N}_{2} \mathrm{O}$, en plus de doses intermittentes de thiopental et de fentanyl. On a mesuré la force de contraction de l'adducteur du pouce suite d des stimulations du nerf cubital en mode train-de-quatre. On a adininistré des doses uniques de $20,30 \mathrm{ou} 40 \mu \mathrm{g} \cdot \mathrm{kg}^{-1}$ de vécuronium, choisies au hasard. On a calculé des courbes de dose-action par

\section{Key words}

MONITORING: neuromuscular function; NEUROMUSCULAR RELAXANTS: vecuronium.

From the Departments of Anaesthesia, Royal Victoria Hospital and McGill University, Montreal, Quebec, Canada, and Service d'anesthésie, Institut Gustave-Roussy, Villejuif, France.

Address correspondence to: Dr. François Donati, Department of Anaesthesia, Royal Victoria Hospital, 687 Pine Avenue West, Montreal, Quebec, Canada H3A IAl.

Accepted for publication 9th April, 1991 . régression linéaire du logit du bloc du premier élément du Irain-de-quatre (TI) versus le logaritlime de la dose. Les sujets anesthésiés à Paris ont eu besoin de $27 \%$ de plus de vécuronium pour le même bloc neuromusculaire (limites de confiance à 95\%: 5-53\%; $P=0.01$ ). A Montréal, les $D A_{50}$ et $D A_{95}$ s'établissaient à ( \pm SEE pour la moyenne) $26,0 \pm 1,4$ el 44,2 \pm $2,5 \mu \mathrm{g} \cdot \mathrm{kg}^{-1}$, respectivement. A Paris, ces valeurs étaient de $33,0 \pm 3,3$ et $71,9 \pm 7,2 \mu \mathrm{g} \cdot \mathrm{kg}^{-1}$, respectivement. Les groupes étaient sensiblement de même age, sexe, poids et taille. Ces résultats comfirmemt, pour le vécuronium, l'existence d'une différence de puissance de part de d'autre de l'Atlantique, semblable à celle qui avait été décrite pour la d-fubocurarine d Londres et à New-York.

Many factors influence the potency of neuromuscular blocking drugs. These include age, ' disease states, ${ }^{2-4}$ and interaction with several drugs. ${ }^{5-8}$ In 1969 , Katz et al. made the intriguing observation that there were transatlantic differences in sensitivity to muscle relaxants. ${ }^{9}$ They observed that, after administration of d-tubocurarine, 0.1 $\mathrm{mg} \cdot \mathrm{kg}^{-1}$, to patients anaesthetized with nitrous oxide and halothane, the mean block of the adductor pollicis muscle in British patients in London was (mean \pm SD) $43 \pm 21 \%$ compared with $75 \pm 14 \%$ in Americans anaesthetized in New York. In addition, the duration of the block (time to $90 \%$ recovery) was reduced from $31.2 \pm 12.4 \mathrm{~min}$ in New York to $14.6 \pm 8.8 \mathrm{~min}$ in London.

The duration of action of succinylcholine, $1 \mathrm{mg} \cdot \mathrm{kg}^{-1}$, was also reduced from $14.6 \pm 3.6 \mathrm{~min}$ in New York to 9.1 $\pm 2.9 \mathrm{~min}$ in London. This transatlantic difference has never been confirmed with the same drugs, or with different neuromuscular blocking agents, or between different cities. Since dosage recommendations are based on potency data, it appears useful to determine whether there are geographical differences in the effect of relaxants used commonly in clinical practice. The present study was undertaken to compare the potency of vecuronium in patients anaesthetized in Montreal or Paris, using identical anaesthetic and neuromuscular monitoring techniques.

\section{Methods}

After approval by the hospitals' Ethics Committees, 19 
patients were studied in Montreal and 18 in Villejuif, a suburb of Paris. All were ASA physical status I or II and were undergoing a variety of elective surgical procedures. Patients with hepatic, renal or neuromuscular diseases were excluded, as were those with malnutrition, electrolyte abnormalities, and those taking any medication known or suspected of interfering with neuromuscular function. Also excluded were patients who deviated from their ideal body weight by more than $20 \%$ and those with excessive alcohol intake. At each centre, patients were randomized to receive one of three doses of vecuronium in a dose range expected to produce only $20-90 \%$ neuromuscular block. An equal number of men and women received each dose. This investigation took place simultaneously in both centres involved, between September and December, 1989.

On arrival in the operating room, the patients' ECG, blood pressure, and oxygen saturation were monitored. Anaesthesia was induced with thiopentone, $5-10 \mathrm{mg}$. $\mathrm{kg}^{-1}$, and fentanyl, $1-3 \mu \mathrm{g} \cdot \mathrm{kg}^{-1}$, and the lungs were ventilated manually with nitrous oxide, $70 \%$, in oxygen. Anaesthesia was maintained with $\mathrm{N}_{2} \mathrm{O}$ and intermittent boluses of thiopentone and fentanyl.

The ulnar nerve was stimulated supramaximally at the wrist via surface electrodes at a frequency of $2 \mathrm{~Hz}$ for 2 $\mathrm{sec}$, and repeated every $20 \mathrm{sec}$. The hand and forearm were immobilized in a splint and the force of contraction of the adductor pollicis was measured with a force displacement transducer (Grass FT10 in Montreal, Bioindustry Curamètre in Paris) and recorded on paper. Stimulation commenced four minutes after induction of anaesthesia and a baseline recording was established. One minute after the start of the stimulation, that is, five minutes after induction of anaesthesia, vecuronium (Norcuron injected by random allocation. The recording was continued until the response to the first stimulus in the train, $\mathrm{T} 1$, was stable for three consecutive trains. At the end of the recording, additional vecuronium was administered to facilitate tracheal intubation.

Dose response curves were constructed from the logit transformation of $\mathrm{T} I$ depression versus the log of the dose of vecuronium, expressed in $\mathrm{mg} \cdot \mathrm{kg}^{-1}$ actual body weight, at each location. The slopes of the curves were compared for parallelism and the groups of data were compared by analysis of covariance. The same analysis was made for logit transformation of $\mathrm{Tl}$ depression against log dose, in $\mathrm{mg}$ per $\mathrm{kg}$ ideal body weight, which was defined as the weight which made the body mass index (BMI) equal 22.5. The BMI is the weight in $\mathrm{kg}$, divided by the square of the height in meters. ${ }^{10} \mathrm{~A} P$ value of $<0.05$ was considered to indicate a statistically significant difference. The results are expressed as mean
TABLE I Demographic data (mean \pm SEM when applicable)

\begin{tabular}{lll}
\hline & Montreal & Paris \\
\hline Number & 19 & 18 \\
Sex (M/F) & $9 / 10$ & $9 / 9$ \\
Age (yr) & $44 \pm 3$ & $51 \pm 3$ \\
Weight (kg) & $65 \pm 3$ & $66 \pm 2$ \\
Height (cm) & $167 \pm 3$ & $168 \pm 2$ \\
\hline
\end{tabular}

TABLE II Potency of vecuronium (mean \pm standard error of estimate for the mean)

\begin{tabular}{|c|c|c|}
\hline & Montreal & Paris \\
\hline \multicolumn{3}{|c|}{ Based on actual body weight: } \\
\hline $\mathrm{ED}_{s 0}\left(\mu \mathrm{g} \cdot \mathrm{kg}^{-1}\right)$ & $26.0 \pm 1.4$ & $33.0 \pm 3.3$ \\
\hline $\mathrm{ED}_{9 g}\left(\mu \mathrm{g} \cdot \mathrm{kg}^{-1}\right)$ & $44.2 \pm 2.5$ & $71.9 \pm 7.2$ \\
\hline \multicolumn{3}{|c|}{ Based on ideal body weight: } \\
\hline $\mathrm{ED}_{50}\left(\mu \mathrm{g} \cdot \mathrm{kg}^{-1}\right)$ & $26.1 \pm 1.6$ & $36.5 \pm 2.5$ \\
\hline $\mathrm{ED}_{95}\left(\mu \mathrm{g} \cdot \mathrm{kg}^{-1}\right)$ & $48.2 \pm 2.9$ & $77.9 \pm 5.4$ \\
\hline
\end{tabular}

values $\pm \mathrm{SEM}$, except for the $\mathrm{ED}_{50}$ and $\mathrm{ED}_{95}$ estimates, which are presented as mean values \pm standard error of estimate for the mean.

\section{Results}

The demographic data are given in Table $\mathrm{l}$. The patients in Paris were slightly older than those in Montreal, but the difference was not statistically different. There were no differences between the two groups regarding sex, weight or height. Both groups received comparable doses of thiopentone: $7.3 \pm 0.8 \mathrm{mg} \cdot \mathrm{kg}^{-1}$ in Montreal, versus 6.8 $\pm 0.9 \mathrm{mg} \cdot \mathrm{kg}^{-1}$ in Paris (NS).

Dose response curves are shown in Figure 1. The slopes of the regression lines did not differ significantly from parallelism. The dose response relationship of the Paris patients was shifted to the right by $27 \%$ (95\% confidence limits: 5-53\%; $P=0.01$ ) with respect to the Montreal patients. Estimates of $E D_{50}$ and $E D_{95}$ are presented in Table II. The time to maximum blockade was independent of dose and was comparable in both groups; i.e., 6.7 $\pm 0.3 \mathrm{~min}$ in Montreal, and $6.3 \pm 0.3 \mathrm{~min}$ in Paris.

When the dose was expressed per kg ideal body weight, the difference between the groups was $41 \%$ (95\% confidence limits 18-81\%; $P=0.001$ ) (Figure 2). Estimates of $\mathrm{ED}_{50}$ and $E D_{95}$ based on ideal body weight are shown in Table II.

\section{Discussion}

The results demonstrated that patients in Paris required approximately $30 \%$ more vecuronium than patients in Montreal to achieve the same degree of neuromuscular 


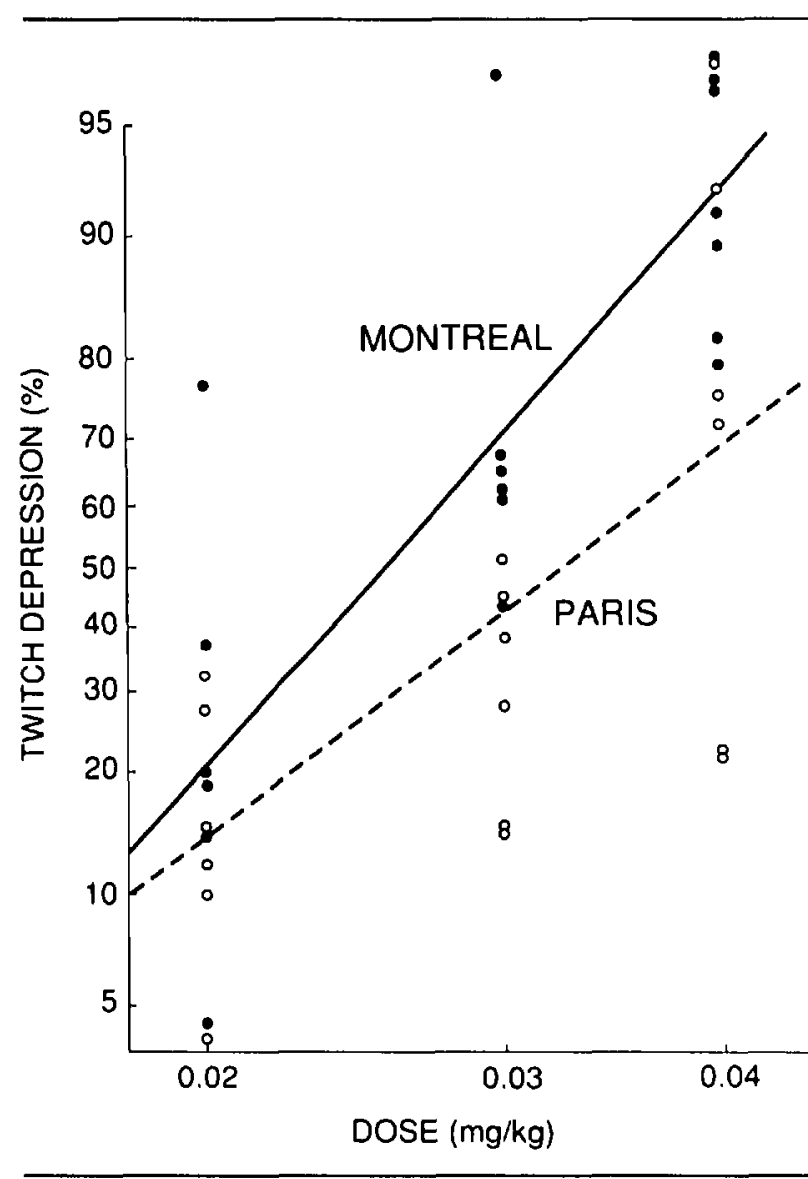

FIGURE I First twitch depression (logit scale) versus dose of vecuronium, in $\mathrm{mg} \cdot \mathrm{kg}^{-1}$ (log scale) for Montreal (solid line and filled circles) and Paris (dashed line and open circles) patients. Lines represent regression lines.

block. This difference cannot be attributed to a different anaesthetic technique, or to a different dose of induction agent. The results are qualitatively similar to the differences found previously by Katz el al. ${ }^{9}$ between New York and London for succinylcholine and d-tubocurarine, despite differences in anaesthetic and monitoring techniques between the two studies.

In the present study, agents which might modify the effects of vecuronium, such as succinylcholine, ${ }^{11,12}$ and anaesthetic vapours ${ }^{5}$ were avoided. Katz et al. used halothane in an inspired concentration of $0.75-1.5 \% .^{9}$ This would tend to potentiate d-tubocurarine and, in particular, prolong its duration of action because of the time taken for halothane to equilibrate in muscle. ${ }^{13}$ The net effect would be accentuated differences in duration of neuromuscular block. The d-tubocurarine was preceded by succinylcholine in half the patients studied by Katz $e t$ al. They observed that the magnitude and duration of the block produced by d-tubocurarine were increased in these patients. Overall, the administration of succinylcholine

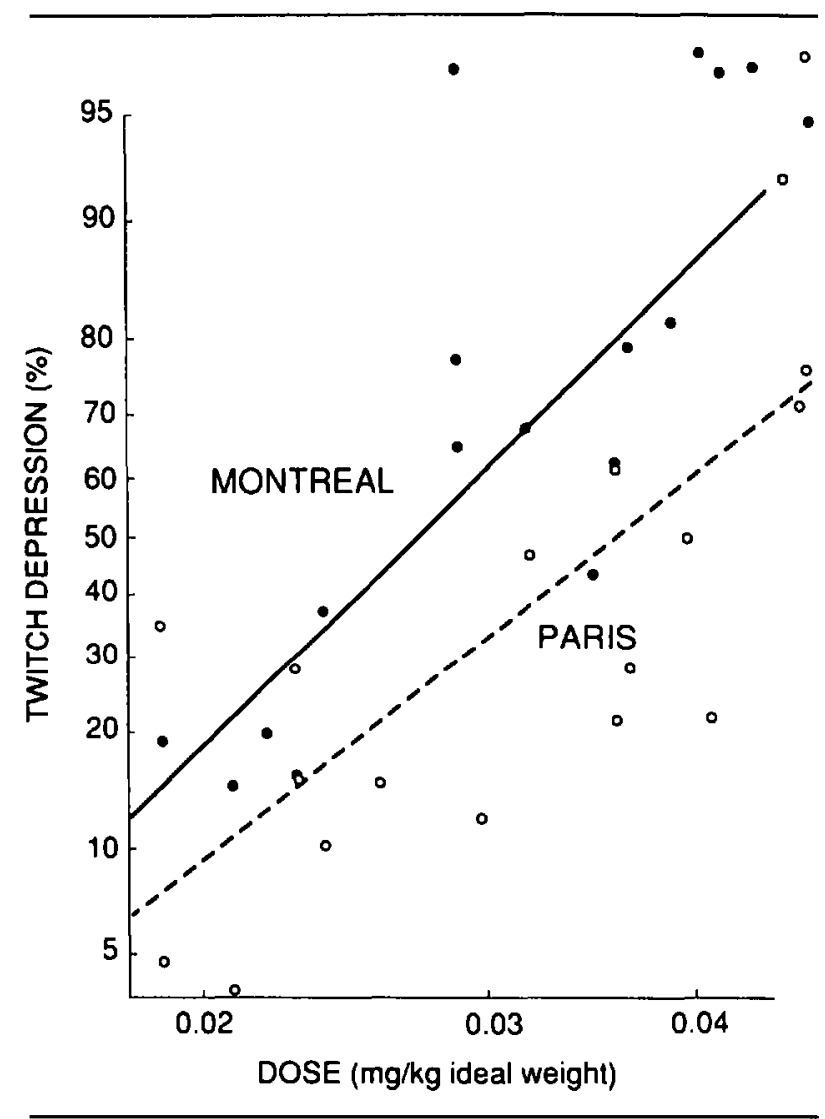

FIGURE 2 First twitch depression (logit scale) versus dose of vecuronium, in $\mathrm{mg} \cdot \mathrm{kg}^{-1}$ ideal body weight (log scale) for Montreal (solid line and filled circles) and Paris (dashed line and open circles) patients. Lines represent regression lines.

may have contributed to their variation in the response to d-tubocurarine. Succinylcholine was avoided in the present study.

Neuromuscular monitoring was performed using a standard methodology - train-of-four stimulation of the ulnar nerve at $<0.1 \mathrm{~Hz}$ and measurement of the force of thumb adduction. Katz et al. used single pulse stimulation of the ulnar nerve at $0.25-0.3 \mathrm{~Hz}$. Increasing the frequency above $0.1 \mathrm{~Hz}$ prevents full recovery of the neuromuscular junction between stimuli and, thus, exaggerates the apparent action of the neuromuscular blocking drug. ${ }^{14}$ Furthermore, onset of action of relaxants depends not only on the type of stimulation, but also on the duration of stimulation before injection of the relaxant. ${ }^{15}$ For this reason, the type of stimulation (train-of-four), the interval between trains $(20 \mathrm{sec})$ and the time when the stimulation was started ( $5 \mathrm{~min}$ after induction and $1 \mathrm{~min}$ before injection of vecuronium) were standardized.

In the previous transatlantic study, ${ }^{9}$ maximum blockade and duration of a bolus dose were compared. In the present study, dose response relationships were obtained. 
TABLE III Potency estimates $\left(\mathrm{ED}_{50}\right.$ in $\left.\mu \mathrm{g} \cdot \mathrm{kg}^{-1}\right)$ for vecuronium found in literature

\begin{tabular}{|c|c|c|c|c|}
\hline & \multicolumn{4}{|c|}{ Halothane $\mathrm{N}_{2} \mathrm{O}$ or narcotic $\mathrm{N}_{2} \mathrm{O}$ anaesthetic only } \\
\hline & \multicolumn{2}{|l|}{ Europe } & \multicolumn{2}{|l|}{ North America } \\
\hline & Location & $E D_{s o}$ & Location & $E D_{50}$ \\
\hline \multirow[t]{8}{*}{ Adults: } & $U^{16}$ & 23.1 & California ${ }^{17}$ & 15.0 \\
\hline & Denmark $^{18}$ & 28.0 & California $^{19}$ & 15.0 \\
\hline & Denmark $^{18}$ & 25.7 & California ${ }^{19}$ & 16.9 \\
\hline & Denmark $^{21}$ & 30.5 & Illinois ${ }^{22}$ & 20.4 \\
\hline & France* & 33.0 & New York ${ }^{7}$ & 28.0 \\
\hline & & & Quebec $^{23}$ & 31.0 \\
\hline & & & Quebec 24 & 23.0 \\
\hline & & & Quebec* & 26.0 \\
\hline Adolescents: & Finland ${ }^{25}$ & 33.0 & Massachusetts $^{26}$ & 23.0 \\
\hline \multirow[t]{2}{*}{ Children: } & France $^{27}$ & 31.0 & Massachuselts ${ }^{26}$ & 33.0 \\
\hline & Finland $^{25}$ & 45.0 & & \\
\hline Mean (range): & \multicolumn{2}{|c|}{$31.2(23.1-45.0$} & \multicolumn{2}{|l|}{$23.1(15.0-33.0)$} \\
\hline
\end{tabular}

"This study.

This allows the determination of equipotent doses; i.e., those producing the same effect in both centres. For example, the present study suggests that $30 \mu \mathrm{g} \cdot \mathrm{kg}^{-1}$ in Montreal is equipotent with $42 \mu \mathrm{g} \cdot \mathrm{kg}^{-1}$ in Paris. The drug was provided by the same company (Organon) in both places, and a systematic discrepancy of this magnitude in manufacturing and packaging appears unlikely. Thus, the difference obtained between Montreal and Paris patients might be due either to different pharmacokinetics, or to different concentration-effect relationships. A kinetic-dynamic study could answer the question, but the number of subjects required would be high, considering the within-group variability.

Potency-estimates for vecuronium reported in the literature vary by a factor greater than two (Table III), and North American researchers tend to report lower $E_{50}$ 's than European investigators. The present study suggests that geographical differences are important and might explain at least part of the discrepancies. Some drugs have been found to be metabolized differently in different ethnic groups, ${ }^{28-31}$ within a given population. ${ }^{31}$ However, metabolism cannot explain differences in the peak effect of a drug, as is the case here. Furthermore, the patient population in Montreal had various ethnic origins (Table IV). Paradoxically, half of the patients studied in Montreal were born in Europe. This suggests that the relative sensitivity of Montreal patients to vecuronium is acquired. This is corroborated by the fact that American citizens living in London for one or two years demonstrated a sensitivity to d-tubocurarine intermediate between
TABLE IV Ethnic backgrounds

\begin{tabular}{lllr}
\hline Montreal & \multicolumn{3}{l}{ Paris } \\
\hline European & 9 & $\begin{array}{l}\text { French } \\
\text { Italian }\end{array}$ & 14 \\
Quebec (French) & 4 & & \\
Quebec (English) & 3 & & \\
North African & 1 & North African & 1 \\
Indian & 1 & & \\
Middle East & 1 & & \\
\hline
\end{tabular}

native London and New York patients. ${ }^{9}$ In the Montreal study, six of the nine patients of European origin had been living in North America for more than ten years.

The differences reported in the present study cannot be attributed to differences in sex ratio, age, height or weight. The seven year age difference between both groups is too small to account for a $30-40 \%$ difference in potency. Height and weight were similar in both groups, suggesting that the relative sensitivity of North American patients was not related to a different body habitus. Furthermore, the difference between centres persists if the dose is expressed as $\mathrm{mg} \cdot \mathrm{kg}^{-1}$ ideal body weight.

Clinically, the $30-40 \%$ difference reported in the present study is much smaller than the inter-individual variability likely to be observed in a given population. ${ }^{32}$ However, the populations studied in Montreal and Paris do not necessarily lie at opposite ends of the potency spectrum. A survey of the literature (Table III) suggests that larger differences might be found. Thus, it is important to base potency estimates of neuromuscular relaxants on data obtained from different geographical areas. These data might lead to slightly different dosage recommendations in different countries.

\section{References}

1 Goudsouzian NG, Donlon JV, Savarese JJ, Ryan $J F$. Re-evaluation of dosage and duration of action of d-tubocurarine in the pediatric age group. Anesthesiology $1975 ; 43: 416-25$.

2 Eisenkraft JB, Book WJ, Papatestas AE. Sensitivity to vecuronium in myasthenia gravis: a dose-response study. Can J Anaesth 1990; 37: 301-6.

3 Moorthy SS, Hilgenberg JC. Resistance to nondepolarizing muscle relaxants in paretic upper extremities of patients with residual hemiplegia. Anesth Analg 1980; 59: 624-7.

4 Martyn JAJ, Szyfelbein SK, Ali HH, Matteo RS, Savarese $J J$. Increased d-tubocurarine requirement following major thermal injury. Anesthesiology 1980; 52: 352-5.

5 Miller RD, Way WL, Dolan WM, Stevens WC, Eger EI II. The dependence of pancuronium- and dtubocurarine-induced neuromuscular blockades on alve- 
olar concentrations of halothane and forane. Anesthesiology 1972; 37: 573-81.

6 Burketl L, Bikhazi GB, Thomas KC, Rosemhal DA, Wirla $M G$, Foldes $F F$. Mutual potentiation of the neuromuscular effects of antibiotics and relaxants. Anesth Analg 1979; 58: 107-15.

7 Ornstein E, Matteo RS, Schwartz AE, Silverberg PA, Young WL, Diaz J. The effect of phenytoin on the magnitude and duration of neuromuscular block following atracurium or vecuronium. Anesthesiology 1987; 67: $191-6$.

8 Matsuo S, Rao DBS, Chaudry I, Foldes FF. Interaction of muscle relaxants and local anesthetics at the neuromuscular junction. Anesth Analg 1978; 57: 580-7.

9 Kalz RL, Norman J, Seed RF, Conrad L. A comparison of the effects of suxamethonium and tubocurarine in patients in London and New York. Br J Anaesth 1969; 41: 1041-7.

10 Pi-Sunyer FX. Obesity. In: Wyngarden JB, Smith LH Jr (Eds.). Cecil Textbook of Medicine 18th ed. Philadelphia: WB Saunders, 1988; 1219-28.

11 d'Hollander AA, Agoston S, DeVille A, Cuvelier F. Clinical and pharmacological actions of a bolus injection of suxamethonium: two phenomena of distinct duration. $\mathrm{Br} \mathrm{J}$ Anaesth 1983; 55: 131-4.

12 Ono K, Manabe N, Ohta Y, Morita K, Kosaka F, Influence of suxamethonium on the action of subsequently administered vecuronium or pancuronium. $\mathrm{Br} \mathrm{J}$ Anaesth 1989; 62: 324-6.

13 Miller RD, Crique M, Eger EI. Duration of halothane anesthesia and neuromuscular blockade with dtubocurarine. Anesthesiology 1976; 62: 206-10.

$14 \mathrm{Ali} \mathrm{HH}$, Savarese JJ. Stimulus frequency and doseresponse curve to d-tubocurarine in man. Anesthesiology 1980; 52: 36-9.

15 Curran MJ, Donati F, Bevan DR. Onset and recovery of atracurium and suxamethonium-induced neuromuscular blockade with simultaneous train-of-four and single twitch stimulation. Br J Anaesth 1987; 59: 989-94.

16 Gibson FM, Mirakhur RK, Clarke RSJ, Lavery GG. Comparison of cumulative and single bolus dose techniques for determining the potency of vecuronium. $\mathrm{Br} \mathrm{J}$ Anaesth 1985; 57: 1060-2.

17 Fahey MR, Morris RB, Miller RD, Sohn YJ, Cronnelly R, Gencarelli $P$. Clinical pharmacology of ORG NC45 (Norcuron (it): a new nondepolarizing muscle relaxant. Anesthesiology 1981; 55: 6-11.

18 Ording H, Skovgaard LT, Engbaek J, Viby-Mogensen $J$. Dose-response curves for vecuronium during halothane and neurolept anaesthesia: single bolus versus cumulative method. Acta Anaesthesiol Scand 1985; 29: $121-4$.
19 Fisher DM, Fahey MR, Cronnelly R, Miller RD. Potency determination for vecuronium (ORG NC45): comparison of cumulative and single-dose techniques. Anesthesiology 1982; 57: 309-10.

20 Rupp SM, Miller RD, Gencarelli PJ. Vecuronium-induced neuromuscular blockade during enflurane, isoflurane, and halothane anesthesia in humans. Anesthesiology 1984; 60: 102-5.

21 Engbaek J, Ording H, Pedersen T, Viby-Mogensen $J$. Dose-response relationships and neuromuscular blocking effects of vecuronium and pancuronium during ketamine anaesthesia. Br J Anaesth 1984; 56: 953-7.

22 O'Hara DA, Fragen RJ, Shanks CA. The effects of age on the dose-response curves for vecuronium in adults. Anesthesiology 1985; 63: 542-4.

23 Bevan DR. Donati F, Gyasi H, Williams A. Vecuronium in renal failure. Can Anaesth Soc J 1984; 31: 491-6.

24 Smith CE, Donati F, Bevan DR. Cumulative doseresponse with infusion: a technique to determine neuromuscular blocking potency of atracurium and vecuronium. Clin Pharmacol Ther 1988; 44: 56-64.

25 Mereloja OA, Wirtavuori $K$, Neuvonen PJ. Agedependence of the dose-response curve of vecuronium in pediatric patients during balanced anaesthesia. Anesth Analg 1988; 67: 21-6.

26 Goudsouzian NG, Martyn JJA, Liu LMP, Gionfriddo $M$. Safety and efficacy of vecuronium in adults and children. Anesth Analg 1983; 62: 1083-8.

27 Meistelman C, Loose JP, Saint-Maurice C, Delleur MM, Da Silva $G L$. Clinical pharmacology of vecuronium in children. Br J Anaesth 1986; 58: 996-1000.

28 Zhou HH, Koshakgi RP, Silberstein DJ, Wilkinson GR, Wood NJJ. Racial differences in drug response: altered sensitivity to and clearance of propranolol in men of Chinese descent as compared with American whites. $N$ Engl J Med 1989; 320: 565-70.

29 Spector R, Choudhury AK, Chiang CK, Goldberg MJ, Ghoneim MM. Diphenhydramine in Orientals and Caucasians. Clin Pharmacol Ther 1980; 28: 229-34.

30 Ghoneim MM, Kortila K, Chiang CK et al. Diazepam effects and kinetics in Caucasians and Orientals. Clin Pharmacol Ther 1981; 29: 749-56.

31 Nakamura K, Goto F, Ray WA et al. Interethnic differences in genetic polymorphism of debrisoquin and mephenytoin hydroxylation between Japanese and Caucasian populations. Clin Pharmacol Ther 1985; 38: 402-8.

32 Katz $R L$. Neuromuscular effects of d-tubocurarine, edrophonium, and neostigmine in man. Anesthesiology 1967; 28: 327-36. 